\title{
Bioelectric properties of cystic fibrosis airways obtained at heart-lung transplantation
}

Eric W F W Alton, Duncan F Rogers, Ronald Logan-Sinclair, Magdi Yacoub, Peter J Barnes, Duncan M Geddes may not be suitable for ion flux measurements.

(Thorax 1992;47:1010-1014)

Over the last decade it has been established that in patients with cystic fibrosis ion transport abnormalities are present in the epithelium of several affected organs. In the airways nasal epithelium from patients with cystic fibrosis generates a substantially more negative potential difference than that of normal subjects. ${ }^{1}$ The apical membrane of these cells shows a reduced permeability, ${ }^{2}$ in keeping with similar findings in the sweat duct ${ }^{3}$ and pancreas. ${ }^{4}$ Furthermore, the response of cystic fibrosis airways to amiloride is greater than that of non-cystic fibrosis tissues, ${ }^{1}$ as is their ouabain-sensitive component of oxygen consumption. ${ }^{5}$ Direct measurements of radiolabelled ion fluxes from nasal tissues have shown discrepant results, ${ }^{67}$ though a significant increase in $\mathrm{Na}^{+}$transport was seen in one study. ${ }^{7}$ Thus $\mathrm{Na}^{+}$absorption across the apical membrane is likely to be increased. This abnormality appears to be unique to the respiratory and gastrointestinal tracts and contrasts with the secondary reduction in movement of $\mathrm{Na}^{+}$across sweat duct epithelium. ${ }^{8}$

In vivo measurements on the lower airways (trachea and more distal) in cystic fibrosis suggest an increased potential difference similar to that in the nose. ${ }^{1}$ Characterisation of tracheobronchial transfected epithelial monolayers ${ }^{9}$ has shown abnormalities in ion transport similar to those in the upper airways, and patch clamp studies of cystic fibrosis lower airway cells maintained in primary culture have shown abnormal regulation of the opening of an outwardly rectifying chloride channel by both protein kinase $A$ and protein kinase $C$ dependent phosphorylation, ${ }^{10-13}$ although the characteristics of this channel differ substantially from the CFTR (cystic fibrosis transmembrane conductance regulator) related chloride channel. ${ }^{14}$

The increasing use of heart-lung transplantation as a therapeutic option for patients with cystic fibrosis provides a source of native lower airway epithelium for a range of studies. This study was designed, firstly, to assess the feasibility of measurement of bioelectric properties and ion fluxes in these airways when mounted in Ussing chambers. Secondly, when mounted under open circuit conditions, these \begin{abstract}
as is the reduced chloride conductanc were seen between non-cystic fibrosis and cystic fibrosis tissues, heavily infected airways from patients with cystic fibrosis tro studies of bioelectric properties The increased response to amiloride
\end{abstract}


airways may provide the closest approximation to the in vivo ion transport prevailing in these end stage lungs. Measurements were therefore made under these conditions. Finally, we assessed the contribution of $\mathrm{Na}^{+}$to the bioelectric properties by the use of amiloride and sodium substitution and that of $\mathrm{Cl}^{-}$by the use of isoprenaline and chloride substitution in the bathing medium.

\section{Methods}

SOURCES OF MATERIAL

Lungs were obtained after heart-lung transplantation from nine patients with cystic fibrosis and five patients with other pulmonary diseases (bronchiectasis 3, $\alpha_{1}$ antitrypsin deficiency 1 , secondary pulmonary hypertension 1). Airways were also obtained from seven patients who did not have cystic fibrosis after pneumonectomy or lobectomy for lung carcinoma. Only tissue macroscopically free of tumour was used for further study. Organs were immediately immersed in $0.9 \%$ saline and transported on ice to the laboratory, where they were transferred into Krebs-Henseleit solution (composition (mmol/l): $\mathrm{Na}^{+} 145 \cdot 0, \mathrm{~K}^{+} 5 \cdot 9$, $\mathrm{Ca}^{2+} 2 \cdot 5, \mathrm{Mg}^{2+} 1 \cdot 2, \mathrm{Cl}^{-} 126 \cdot 0, \mathrm{HCO}_{3}{ }^{-} 26 \cdot 0$, $\mathrm{PO}_{4}^{2-} 1 \cdot 2, \mathrm{SO}_{4}^{2-} 1 \cdot 2$, glucose $5 \cdot 6, \mathrm{pH} 7 \cdot 4$ ) and bubbled with $95 \%$ oxygen and $5 \%$ carbon dioxide.

\section{MEASUREMENT OF BIOELECTRICAL PROPERTIES}

Bronchi were cleared of surrounding tissue and their outer diameter was recorded. Airways with an outer diameter of $1.2 \mathrm{~cm}$ or more are referred to as proximal and of less than $1.2 \mathrm{~cm}$ as distal. Bronchial segments were cut longitudinally for mounting in Ussing chambers of internal cross sectional area $0.28 \mathrm{~cm}^{2}$. No attempt was made to remove any secretions from the mucosal surface. Tissues were bathed with warm $\left(37^{\circ} \mathrm{C}\right.$ ) $\mathrm{Krebs}$ solution ( $9 \mathrm{ml}$ each side), which was circulated by means of gas lift pumps ( $95 \%$ oxygen, $5 \%$ carbon dioxide). A few minutes after the tissues had been mounted both chambers were drained of Krebs solution to remove excess bronchial secretions and fresh solution was substituted. Potential difference was measured with $2 \%$ agar bridges containing $1 \mathrm{M} \mathrm{KCl}$ placed in close proximity to the tissues, which were linked via calomel half cells (Russell pH Ltd, Fife) to an automatic voltage clamp (World Precision Instruments DVC 1000, New Haven, Connecticut) and recording computer (department of biomedical engineering, Royal Brompton and National Heart Hospitals). Before tissue mounting the offset potential of the electrodes was measured and suitable adjustments were made to the recorded values. Tissues were studied under open circuit conditions except for brief periods, when the tissue was short circuited to zero voltage by passing current through $2 \%$ agar-saline bridges via silver-silver chloride electrodes, to record short circuit current (Isc). Conductance was calculated from Ohm's law. Tissues with a conductance greater than $14 \mathrm{~ms} / \mathrm{cm}^{2}$ were discarded. ${ }^{15}$ The number of tissues that fulfilled this criterion were: from the 12 patients without cystic fibrosis, 51 bronchial segments (mean 4, range $2-9$ per lung) and from the nine patients with cystic fibrosis 48 bronchial segments (mean 3, range 2-9 per lung). After the studies of bioelectric properties or ion fluxes or both the data obtained from all bronchial segments of any one patient were averaged (reported $n$ values are the number of patients studied, unless otherwise indicated).

\section{MEASUREMENT OF ION FLUXES}

After stabilisation of the potential difference (generally $0 \cdot 5-1$ hour) $10 \mu \mathrm{Ci}$ each of ${ }^{22} \mathrm{Na}$ and ${ }^{36} \mathrm{Cl}$ (Amersham International, Amersham) were added to one side of the chamber. One millilitre of Krebs solution was sampled from the contralateral side every 15 minutes and replaced by $1 \mathrm{ml}$ Krebs. solution without isotopes ("cold" Krebs). Every 45 minutes $50 \mu \mathrm{l}$ Krebs solution was removed from the ipsilateral chamber, this volume not being replaced; $950 \mu \mathrm{l}$ of cold Krebs solution was added to these samples to correct for quench. Ten millilitres of scintillant (Ultima Gold, Canberra Packard, Pangbourne) was added to each sample and the activity was counted in a liquid scintillation counter (Canberra Packard 2200 CA, Pangbourne) for 30 minutes. The spectrum distribution for each isotope was obtained and analysed. By setting up appropriate regions of interest the isotope activity was calculated by proprietary dual label DPM calculation methods to give the activity of each isotope. Uniformity of quench was monitored by the external standard channels method. In preliminary experiments the time for isotopic fluxes to reach equilibration was assessed. For proximal airways this was 75 minutes and for distal airways was $\mathbf{4 5}$ minutes. After equilibration four $1 \mathrm{ml}$ samples were taken and a mean value was calculated. Tissues were paired from each lung on the basis of a less than $20 \%$ difference in conductance ${ }^{15}$ for calculation of net fluxes.

\section{DRUG EFFECTS ON BIOELECTRIC PROPERTIES}

Following stabilisation of the potential difference drugs were added to the mucosal (amiloride $10 \mu \mathrm{M}^{7}$ ) or serosal (isoprenaline $100 \mu \mathrm{M}^{16}$ ) sides of the chamber (final concentrations) and bioelectic properties were recorded for one hour. In experiments determining the effects of sodium or chloride substituted solutions on bioelectric properties the mucosal side of the chamber was drained of Krebs solution and rinsed several times with the appropriate solution (see below) before being refilled. Junctional potentials between sodium or chloride substituted Krebs and normal Krebs solutions were measured in two ways. Either filter paper (Whatman Grade 1, $11 \mu \mathrm{m}$ pore, Whatman International Ltd, Maidstone) was mounted in the chambers and bathed asymmetrically with the two solutions or calomel electrodes were placed in containers of each solution linked by a $1 \mathrm{M} \mathrm{KCl} 2 \%$ agar bridge. Values were similar with the two techniques (mean (SE) $1.3 \mathrm{mV}$ $(0 \cdot 2), \mathrm{n}=29$, for sodium free Krebs and $-5 \cdot 1$ $\mathrm{mV}(0 \cdot 6), \mathrm{n}=6$, for chloride substituted Krebs). Suitable adjustments were made in the recorded values for these potentials. 
Table 1 Maximal baseline bioelectric properties (mean $(S E)$ of non-cystic fibrosis (CF) and cystic fibrosis airways

\begin{tabular}{|c|c|c|c|c|}
\hline$O D(\mathrm{~cm})$ & $n$ & $P D(m V)$ & $I s c\left(\mu A / \mathrm{cm}^{2}\right)$ & $G\left(\mathrm{~ms} / \mathrm{cm}^{2}\right)$ \\
\hline \multicolumn{5}{|c|}{ Non-CF } \\
\hline$<1 \cdot 2$ & 9 & $3 \cdot 1(0 \cdot 6)$ & $30 \cdot 9(4 \cdot 7)$ & $10 \cdot 7(0 \cdot 6)$ \\
\hline$\geqslant 1 \cdot 2$ & 10 & $4 \cdot 1(0.5)$ & $38.5(5 \cdot 6)$ & $9.3(0.5)$ \\
\hline Áll & 12 & $3.6(0.5)$ & $33 \cdot 7(3 \cdot 7)$ & $9.8(0.4)$ \\
\hline \multicolumn{5}{|c|}{$C F$} \\
\hline$<1 \cdot 2$ & 7 & $3 \cdot 1(0 \cdot 2)$ & $30 \cdot 3(1 \cdot 8)$ & $10 \cdot 4(0 \cdot 4)$ \\
\hline$\geqslant 1 \cdot 2$ & 7 & $4.5(0.8)$ & $32 \cdot 0(4 \cdot 7)$ & $7.7(0.4)^{\star \star \star \star}$ \\
\hline Áll & 9 & $3 \cdot 6(0 \cdot 3)$ & $30.5(2.5)$ & $9 \cdot 3(0.4)$ \\
\hline
\end{tabular}

OD—outer diameter; PD—potential difference; Isc-short circuit current; $\mathrm{G}$-conductance.

DRUGS

Amiloride $\mathrm{HCl}$ was a generous gift of Merck, Sharpe, and Dohme. Isoprenaline was purchased from Sigma Chemical Co Ltd, Poole. In the sodium substituted Krebs solution sodium chloride was replaced by equimolar choline chloride and sodium bicarbonate by choline bicarbonate. In the chloride substituted Krebs solution sodium chloride was replaced by equimolar sodium gluconate (final chloride concentration $11 \mathrm{mmol} / \mathrm{l})$. All chemicals were of AnalaR or best available grade.

\section{STATISTICS}

Pre-drug and post-drug effects on absolute changes in bioelectric properties and ion fluxes were compared by means of Student's $t$ test (two tailed). The significance of changes from baseline within a group was assessed by the Wilcoxon signed rank test (two tailed). The null hypothesis was rejected at values of $\mathrm{p}<0.05$. Results are expressed as means with standard errors in parentheses in all comparisons.

\section{Results}

BASAL BIOELECTRIC PROPERTIES

In non-cystic fibrosis airways there was no significant difference in maximal potential difference between size matched resection and transplant tissue $(<1.2 \mathrm{~cm}$ outer diameter: resection $-3 \cdot 7(1 \cdot 1) \mathrm{mV}, \mathrm{n}=5$; transplant $-2.4(0.2) \mathrm{mV}, \mathrm{n}=4 ; \geqslant 1.2 \mathrm{~cm}$ outer diameter: resection $-4.5(0.7) \mathrm{mV}, \mathrm{n}=5$, transplant $-3.7 \mathrm{mV}(0.7), \mathrm{n}=5)$. Data were therefore pooled and baseline values for all

Percentage reduction in potential difference ( $P D$ ) and short circuit current (Isc) in non-cystic fibrosis (open columms) and cystic fibrosis (solid columns bronchi in response amiloride $10 \mu \mathrm{M}$ mucosally). The figures at the base of the columns indicate numbers of patients and vertical bar standard errors. $\star p<0.05$ in the $p<0.05$ in the
comparison with non-cystic fibrosis airways.

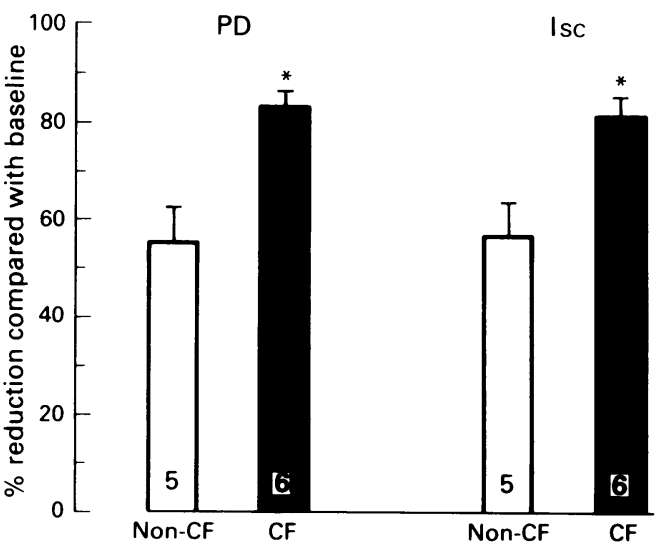

non-cystic fibrosis airways are shown in table 1 . There was no difference in potential difference (PD), short circuit current (IsC), and conductance $(G)$ between proximal and distal airways. After the initial stabilisation period PD slowly declined in all tissues over the period of the experiment $(<1.2 \mathrm{~cm}$ : by $14.4 \%(1.8 \%) / \mathrm{h}$ of basal value; $\geqslant 1.2 \mathrm{~cm}$ : by $10.8 \%(2 \cdot 4 \%) / \mathrm{h}$ of basal value), whereas resistance changed little $(<1.2 \mathrm{~cm}:$ reduced by $0.6 \% \quad(0.1 \%) / \mathrm{h}$; $\geqslant 1.2 \mathrm{~cm}$ : increased by $0.6 \%(0.1 \%) / \mathrm{h})$.

Baseline values for cystic fibrosis tissues are also shown in table 1 . There was no difference in PD and Isc between distal and proximal airways: $G$, however, was significantly higher $(\mathrm{p}<0.001)$ in distal airways. PD declined by $15.6 \%(2.4 \%) / \mathrm{h}$ in tissues below $1.2 \mathrm{~cm}$ and by $16.2 \%(3.0 \%) / \mathrm{h}$ in airways of $1.2 \mathrm{~cm}$ or more. Resistance increased by $3.6 \%(1.8 \%) / \mathrm{h}$ irrespective of airway size. There were no significant differences in baseline bioelectric properties between the cystic fibrosis and non-cystic fibrosis groups. Furthermore, the ranges of PD were similar in the two groups (non-cystic fibrosis: $<1.2 \mathrm{~cm}, 1.1-6.8 \mathrm{mV}, \geqslant 1.2 \mathrm{~cm}, 1.8$ $5.8 \mathrm{mV}$; cystic fibrosis: $<1.2 \mathrm{~cm}, 2.6-3.8 \mathrm{mV}$; $\geqslant 1.2 \mathrm{~cm}, 2.4-7.6 \mathrm{mV}$ ). For further analysis values for proximal and distal airways within each of the two groups were combined.

EFFECT OF DRUGS ON BIOELECTRIC PROPERTIES The mean response of non-cystic fibrosis and cystic fibrosis airways to amiloride is shown in the figure. Cystic fibrosis bronchi responded with a significantly $(p<0.05)$ greater percentage fall in PD and Isc from baseline values than did non-cystic fibrosis tissues. The mean (SE) absolute reductions were: non-CF, -1.6 $(0.3, \mathrm{n}=5) \mathrm{mV}$ from a baseline of $-3.3(0.8)$ $\mathrm{mV}$ and $14.4(2.0) \mu \mathrm{A} / \mathrm{cm}^{2}$ from a baseline of $\left.28.5 \mu \mathrm{A} / \mathrm{cm}^{2} ; \mathrm{CF},-1.7(0.2) \mathrm{mV}, \mathrm{n}=6\right)$ from a baseline of $-2 \cdot 2(0.2) \mathrm{mV}$ and $16.4(2 \cdot 0)$ $\mu \mathrm{A} / \mathrm{cm}^{2}$ from a baseline of $20.9(2 \cdot 1) \mu \mathrm{A} / \mathrm{cm}^{2}$. There was no significant change in $\mathrm{G}$ in either set of tissues. Sodium substitution reduced mean PD by $95.0 \%(5.9)$ in four tissues from two patients with cystic fibrosis and a combination of amiloride and sodium substitution by $77 \cdot 0 \%(7 \cdot 7 \%)$ in seven tissues from two patients without cystic fibrosis.

Isoprenaline produced little change in any bioelectric measurement in six non-cystic fibrosis tissues from two patients (PD: $-1.5 \%$ $(0.7 \%)$; Isc: $-0.2 \% \quad(2.9 \%) ; \mathrm{G}:+1.3 \%$ $(3 \cdot 1 \%)$ but increased PD $(+26 \cdot 2 \%(6.3 \%)$, $\mathrm{p}<0.01)$ and IsC $(+24.4 \% \quad(5.0 \%)$, $\mathrm{p}<0.001)$ in seven cystic fibrosis airways from two patients (mean increase $0.8(0.2) \mathrm{mV}$, $\mathrm{n}=7$ ). After pretreatment of three cystic fibrosis tissues from one patient with amiloride (10 $\mu \mathrm{M}$, mucosally) isoprenaline produced increases in PD of $0.3,0.1$, and $0.4 \mathrm{mV}$. Replacement of chloride in the mucosal bathing medium with gluconate produced no significant change in any bioelectric parameter in five cystic fibrosis airways from two patients.

ISOTOPIC FLUXES

Basal values for all non-cystic fibrosis tissues, irrespective of airway diameter, are shown in 
Table 2 Mean (SE) ion fluxes $\left(\mu E q / \mathrm{cm}^{2} / \mathrm{h}\right)$ in cystic fibrosis (CF) and non-cystic fibrosis bronchi

\begin{tabular}{lrrrr}
\hline $\begin{array}{l}\text { Ion and flux } \\
\text { direction }\end{array}$ & Non-CF & $n$ & \multicolumn{1}{l}{ CF } & $n$ \\
\hline & & $N a^{\prime}$ & & \\
m-s & $3.6(0.3)$ & 6 & $3.2(0.6)$ & 5 \\
s-m & $3.4(0.2)$ & 6 & $4.3(0.3)$ & 5 \\
net & $0.2(0.3)$ & 6 & $-1.0(0.5)$ & 5 \\
& & & & \\
m-s & $4.5(0.4)$ & & $4 \cdot 1(0.6)$ & \\
s-m & $4.5(0.3)$ & & $4.8(0.5)$ & \\
net & $0.0(0.4)$ & & $-0.6(0.5)$ & \\
\hline
\end{tabular}

Positive values indicate net absorption. Conductances were: non-CF, ms: $9.3(0.3) \mathrm{ms} / \mathrm{cm}^{2} ; \mathrm{sm}: 9.0(0.5) \mathrm{ms} / \mathrm{cm}^{2}$; CF, ms: $10 \cdot 1(0 \cdot 7) \mathrm{ms} / \mathrm{cm}^{2} ; \mathrm{s}-\mathrm{m}: 10 \cdot 4(0 \cdot 3) \mathrm{ms} / \mathrm{cm}^{2} . \mathrm{m}-\mathrm{s}-$ mucosal to serosal; sm-serosal to mucosal.

table 2. No significant net $\mathrm{Na}^{+}$or $\mathrm{Cl}^{-}$fluxes were detectable. Respective values for distal airways $(\mathrm{n}=3)$ were $\mathrm{Na}^{+} 1 \cdot 1 \mu \mathrm{Eq} / \mathrm{cm}^{2} / \mathrm{h}, \mathrm{Cl}^{-}$ $1.4 \mu \mathrm{Eq} / \mathrm{cm}^{2} / \mathrm{h}$; and for proximal airways (n=5): $\mathrm{Na}^{+}-0.2 \mu \mathrm{Eq} / \mathrm{cm}^{2} / \mathrm{h}, \mathrm{Cl}^{-}-0.7 \mu \mathrm{Eq} /$ $\mathrm{cm}^{2} / \mathrm{h}$. There was no significant correlation between $\mathrm{G}$ and $\mathrm{Na}^{+}$or $\mathrm{Cl}^{-}$fluxes in either the presumed passive directions $\left(\mathrm{Na}^{+}\right.$serosal to mucosal (s-m): $\mathrm{r}=0.57 ; \mathrm{Cl}^{-}$mucosal to serosal $(m-s): r=0.67)$ or the active directions $\left(\mathrm{Na}^{+} \mathrm{m}-\mathrm{s}: \mathrm{r}=0.40, \mathrm{Cl}^{-} \mathrm{s}-\mathrm{m}: \mathrm{r}=-0.04\right)$.

Again, for cystic fibrosis tissues (table 2) no net fluxes of either ion were detected, nor was there any significant difference between cystic fibrosis and non-cystic fibrosis values for any measurement. In particular, no increase in $\mathrm{Na}^{+}$ $\mathrm{m}-\mathrm{s}$ was seen in the cystic fibrosis tissues, nor any reduction in $\mathrm{Cl}^{-} \mathrm{s}-\mathrm{m}$. Mean conductances of the two groups were not significantly different. No significant correlation of fluxes with $G$ was seen in the presumed passive directions $\left(\mathrm{Na}^{+} \mathrm{s}-\mathrm{m}: \mathrm{r}=0.71 ; \mathrm{Cl}^{-} \mathrm{m}-\mathrm{s}: \mathrm{r}=0.74\right)$ or active directions $\left(\mathrm{Na}^{+} \mathrm{m}-\mathrm{s}: \mathrm{r}=0.60 ; \mathrm{Cl}^{-} \mathrm{s}-\mathrm{m}\right.$ : $r=0 \cdot 84$ ).

\section{Discussion}

Lack of sufficient suitable tissue has hindered study of the bioelectric properties of native cystic fibrosis lower airways. The recent option. of heart-lung transplantation for treatment of patients with cystic fibrosis has provided a source, though a still limited one, of tissue from this principle site of disease in cystic fibrosis. We have assessed the feasibility of using this tissue source for studies of airway ion transport.

We found that the potential difference did not differ significantly in size matched airways from patients with and without cystic fibrosis. A similar finding has been noted in the cultured epithelium of sweat ducts from patients with cystic fibrosis. ${ }^{17}$ Despite our attempts to minimise tissue damage, possibly severe infection and tenacious secretions induced changes in epithelial confluence, leading to short circuiting of the potential difference. Recordings of lower airway potential difference in two patients with cystic fibrosis in vivo showed only patches of raised potential difference over a range of airway levels studied. ${ }^{18}$ Similar considerations may relate to bioelectric measurements in vitro and explain, at least in part, the failure to detect a raised potential difference in the cystic fibrosis tissues of our study. The significantly lower conductance in proximal cystic fibrosis tissues may indicate that such tissues are less damaged than more distal and may therefore be used preferentially for further studies.

Nevertheless, the abnormalities in the bioelectric properties previously described in the upper airways appear to be present also in the native cystic fibrosis lower airways we have studied. Thus the characteristically greater fall in potential difference in cystic fibrosis than in non-cystic fibrosis upper airways in response to amiloride was consistently seen in airways of either size. Furthermore, replacement of the mucosal bathing medium with sodium substituted Krebs solution produced a fall in potential difference of a magnitude similar to that seen with amiloride in cystic fibrosis tissues. The $54 \%$ fall in potential difference with amiloride in non-cystic fibrosis airways is consistent with previous findings, ${ }^{15}$ whereas the $77 \%$ reduction with a combination of amiloride and sodium substitution is in agreement with our recent findings of non-amiloride sensitive sodium transport in sheep and human airways. ${ }^{19}$

Non-cystic fibrosis bronchi showed no change in potential difference in response to the $\beta_{2}$ adrenoceptor agonist isoprenaline. Recent intracellular microelectrode studies showed a similar lack of effect in human nasal epithelial cells. ${ }^{20}$ The lack of a suitable driving force for $\mathrm{Cl}^{-}$secretion across non-cystic fibrosis airways may explain these findings. In contrast, in cystic fibrosis bronchi isoprenaline produced a $26 \%$ rise in potential difference. Similar findings in cystic fibrosis nasal epithelium have been shown to relate to a paradoxical increase in $\mathrm{Na}^{+}$ absorption in the presence of a negligible apical $\mathrm{Cl}^{-}$conductance. ${ }^{16}$ In the present study pretreatment with amiloride reduced the changes in bioelectric properties in response to isoprenaline, suggesting that a mechanism similar to that in the nose may operate in the lower airways in cystic fibrosis. Further support for a lack of $\mathrm{Cl}^{-}$transport in these airways was obtained with mucosal chloride substituted Krebs solution. If allowance is made for junctional potentials, no change in potential difference was seen in four cystic fibrosis tissues.

To our knowledge, there has only been one other study of ion transport across human lower airways and this, owing to the nature of the resected material, was restricted to segmental and subsegmental airways. ${ }^{15}$ In the present study, because of the availability of whole lungs after heart-lung transplantation, we were able to study ion fluxes in both proximal and distal airways, though because of the small numbers in such subcomponents of the study statistical analyses were not warranted. In addition, in contrast to the previous study, ${ }^{15}$ where experiments were conducted principally under short circuit conditions, we chose to study our tissues primarily under open circuit in an attempt to reproduce more closely the conditions in the patients' airways. In the proximal airways under baseline conditions the trend 
was for no net movement of either $\mathrm{Na}^{+}$or $\mathrm{Cl}^{-}$ to be seen. Absence of net ion movement is also characteristic of canine mainstem bronchi. ${ }^{21}$ In contrast, in distal airways about $1 \mu \mathrm{Eq} / \mathrm{cm}^{2} / \mathrm{h}$ of $\mathrm{Na}^{+}$accompanied by an equivalent movement of $\mathrm{Cl}^{-}$was seen. Knowles et $\mathrm{al}^{15}$ also found net absorption of $\mathrm{Na}^{+}$in peripheral human airways under both open and short circuit conditions, values for the former being very similar to those obtained in this study. Similar data have also been reported for peripheral airways in the sheep ${ }^{22}$ and $\operatorname{dog}^{21}$ The relatively greater contribution of proximal airways to our pooled flux data is reflected in the lack of net ion fluxes for these values.

We also studied the feasibility of characterising $\mathrm{Na}^{+}$and $\mathrm{Cl}^{-}$fluxes across these "end stage" cystic fibrosis airways which were occluded with tenacious purulent secretions before being mounted. We were not able to show an increased $\mathrm{Na}^{+}$ms or a reduction in $\mathrm{Cl}^{-} \mathrm{sm}$ in these tissues. With respect to the latter, however, if the CFTR related $\mathrm{Cl}^{-}$channel is functional only during stimulation mediated by cyclic adenosine monophosphate, measurements made under basal conditions are unlikely to be altered. The lack of a significant difference in conductance between all non-cystic fibrosis tissues (mean (SE) $9.4(0.3) \mathrm{ms} / \mathrm{cm}^{2}, \mathrm{n}=51$ ) and all cystic fibrosis tissues $\left(9.3(0.4) \mathrm{ms} / \mathrm{cm}^{2}\right.$, $\mathrm{n}=47$ ) would not suggest substantial alterations in the permeability of paracellular pathways. Subtle changes in transcellular ion movements in cystic fibrosis tissues may, however, have been masked by "noise" from altered paracellular transport under these conditions. In keeping with this, cystic fibrosis tissues showed larger correlation coefficients for fluxes in the presumed active directions (for example, $\mathrm{Cl}^{-}$sm: $\mathrm{r}=-0.04$ for non-cystic fibrosis and 0.84 for cystic fibrosis).

In conclusion, we have shown the feasibility of studying bioelectric properties of lower airways obtained at heart-lung transplantion from patients with and without cystic fibrosis. In native cystic fibrosis lower airways the increased amiloride response and reduced chloride conductance, which have been previously found in upper airways, appear to be retained. Ion flux measurements in non-cystic fibrosis airways under open circuit conditions show no net ion movement, though more distal tissues appear to differ from proximal airways in showing net $\mathrm{Na}^{+}$absorption. We were unable to show an increase in net $\mathrm{Na}^{+}$absorption in cystic fibrosis airways, though such heavily infected tissues may not be well suited to ion flux measurements.

We would like to thank the theatre staff at Harefield and Royal Brompton and National Heart Hospitals for their cooperation; Mr P Goldstraw for access to resected airways; Mr G Pierce for
help with the isotopic measurements; Drs M Hodson, V Tsang,
R Knight, P Jeffery, and R Sharma for help with obtaining tissues; Professor A Cuthbert for helpful discusssions; and the Cystic Fibrosis Research Trust and British Lung Foundation for funding the project. EA was supported by a Medical Research Council training fellowship.

1 Knowles M, Gatzy J, Boucher R. Increased bioelectric potential difference across respiratory epithelia in cystic fibrosis. N Engl J Med 1981;305:1489-95.

2 Willumsen NJ, Davis CW, Boucher RC. Cellular $\mathrm{Cl}^{-}$ transport in cultured cystic fibrosis airway epithelium. $\mathrm{Am}$ J Physiol 1989;256:C1045-53.

3 Quinton PM. Chloride impermeability in cystic fibrosis. Nature 1983;301:421-2.

4 Kopelman H, Durie P, Gaskin K, Weizman Z, Forstner G. Pancreatic fluid secretion and protein hyperconcentration in cystic fibrosis. $N$ Engl $J$ Med 1985;312:329-34.

5 Stutts MJ, Knowles MR, Gatzy JT, Boucher RC. Oxygen consumption and ouabain binding sites in cystic fibrosis nasal epithelium. Pediatr Res 1986;20:1316-20.

6 Knowles M, Gatzy J, Boucher R. Relative ion permeability of normal and cystic fibrosis nasal epithelium. J Clin Invest 1983;71:1410-7.

7 Knowles MR, Stutts MJ, Spock A, Fischer N, Gatzy JT, Boucher RC. Abnormal ion permeation through cystic fibrosis respiratory epithelium. Science 1983;221: 1067-70.

8 Quinton PM. Cystic fibrosis: a disease in electrolyte transport. FASEB J 1990;4:2709-17.

9 Jetten AM, Yankaskas JR, Stutts MJ, Willumsen NJ, Boucher RC. Persistence of abnormal chloride conducBoucher RC. Persistence of abnormal chloride conducScience 1989;244:1472-5.

10 Hwang T-C, Lu L, Zeitlin PL, Gruenert DC, Huginar R, Guggino WB. $\mathrm{Cl}^{-}$channels in $\mathrm{CF}$ : lack of activation by protein kinase $C$ and cAMP-dependent protein kinase. Science 1989;244:1351-3.

11 Li M, McCann JD, Liedtke CM, Nairn AC, Greengard P, Welsh MJ. Cyclic AMP-dependent protein kinase opens chloride channels in normal but not cystic fibrosis airway epithelium. Nature 1988;332:358-60.

12 Li M, McCann JD, Anderson MP, Clancy JP, Liedtke CM Nairn AC, et al. Regulation of chloride channels by protein kinase $\mathrm{C}$ in normal and cystic fibrosis airway epithelia. Science 1989;244:1353-6.

13 Schoumacher RA, Shoemaker RL, Halm DR, Tallant EA, Wallace RW, Frizzell RA. Phosphorylation fails to activate chloride channels from airway cells. Nature 1987;330:752-4.

14 Berger HA, Anderson MP, Gregory RJ, Thompson S, Howard PW, Maurer RA, et al. Identification and regulation of the cystic fibrosis transmembrane conductance regulator-generated chloride channel. $J$ Clin Invest 1991;88:1422-31.

15 Knowles M, Murray G, Shallal J, Askin F, Ranga V, Gatzy $\mathrm{J}$, et al. Bioelectric properties and ion flow across excised human bronchi. J Appl Physiol 1984;56:868-77.

16 Boucher RC, Stutts MJ, Knowles MR, Cantley L, Gatzy JT. $\mathrm{Na}^{+}$transport in cystic fibrosis respiratory epithelia: abnormal basal rate and response to adenylate cyclase activation. J Clin Invest 1986;78:1245-52.

17 Cuthbert AW, Brayden DJ, Dunne A, Smyth RL, Wallwork $\mathrm{J}$. Altered sensitivity to amiloride in cystic fibrosis. Observations using cultured sweat glands. Br J Clin Pharmacol 1990;29:227-34.

18 Alton EWFW, Khagani A, Taylor RFH, Logan-Sinclair R Yacoub M, Geddes DM. Effect of heart-lung transplantation on airway potential difference in patients with and without cystic fibrosis. Eur Respir J 1991;4:5-9.

19 Graham A, Steel D, Alton EWFW, Geddes DM. Second messenger regulation of sodium absorption in mammalian airway epithelia. J Physiol 1992;453:475-91.

20 Willumsen NJ, Davis W, Boucher RC. Intracellular $\mathrm{Cl}^{-}$ activity and cellular $\mathrm{Cl}^{-}$pathways in cultured human airway epithelium. Am J Physiol 1989;256:C1033-44.

21 Boucher RC, Stutts MJ, Gatzy JT. Regional differences in bioelectric properties and ion flow in excised canine airways. J Appl Physiol 1981;51:706-19.

22 Cotton CU, Lawson EE, Boucher RC, Gatzy JT. Bioelectric properties and ion transport of airways excised from adul and fetal sheep. J Appl Physiol 1983;55:1542-9. 